\title{
Gastric Cancer Stem Cells Effect on Th17/Treg Balance; A Bench to Beside Perspective
}

\author{
Alaleh Rezalotfi ${ }^{1,2}$, Elmira Ahmadian ${ }^{3}$, Hossein Aazami ${ }^{4,5}$, Ghasem Solgi $^{1 *}$ and \\ Marzieh Ebrahimi ${ }^{2 *}$
}

${ }^{1}$ Department of Immunology, School of Medicine, Hamadan University of Medical Sciences, Hamadan, Iran, ${ }^{2}$ Department of Stem Cells and Developmental Biology, Cell Science Research Center, Royan Institute for Stem Cell Biology and Technology, ACECR, Tehran, Iran, ${ }^{3}$ Faculty of Biological Sciences and Technology, Department of Animal Sciences, Shahid Beheshti University, Tehran, Iran, ${ }^{4}$ Metabolic Disorders Research Center, Endocrinology and Metabolism Molecular-Cellular Sciences Institute, Tehran University of Medical Sciences, Tehran, Iran, ${ }^{5}$ Students Scientific Research Center, Tehran University of Medical Sciences, Tehran, Iran

OPEN ACCESS

Edited by:

Arian Dominic John Laurence, University College London Hospitals NHS Foundation Trust,

United Kingdom

Reviewed by:

Chao Wang,

Brigham and Women's Hospital,

United States

Qian Chen,

Huazhong University of Science and

Technology, China

*Correspondence:

Ghasem Solgi

gh.solgi@umsha.ac.ir

Marzieh Ebrahim

mebrahimi@royaninstitute.org

Specialty section:

This article was submitted to

Cancer Immunity and Immunotherapy,

a section of the journal

Frontiers in Oncology

Received: 23 September 2018

Accepted: 13 March 2019

Published: 05 April 2019

Citation:

Rezalotfi A, Ahmadian E, Aazami H, Solgi $G$ and Ebrahimi M (2019) Gastric

Cancer Stem Cells Effect on

Th17/Treg Balance; A Bench to

Beside Perspective.

Front. Oncol. 9:226.

doi: 10.3389/fonc.2019.00226
Gastric cancer stem cells (GCSCs), a small population among tumor cells, are responsible for tumor initiation, development, metastasis, and recurrence. They play a crucial role in immune evasion, immunomodulation, and impairment of effector immunity and believed to be emerged to change the balance of the immune system, importantly $\mathrm{CD}^{+}{ }^{+} \mathrm{T}$ cells in the chronic inflamed tumor site. However, different subtypes of innate and adaptive immune cells are involved in the formation of the immune system in the tumor microenvironment, we would look at T cells in this study. Tumor microenvironment induces differentiation of $\mathrm{CD} 4^{+} \mathrm{T}$ cells into different subsets of $\mathrm{T}$ cells, mainly suppressive regulatory T cells (Treg), and T helper 17 (Th17) cells, although their exact role in tumor immunity is still under debate depending on tumor types and stages. Counterbalance between Th17 and Treg cells in the gastrointestinal system result in the homeostasis and normal function of the immune system, particularly mucosal immunity. Recent data demonstrated a high infiltration of Th17 and Treg cells into the gastric tumor site and proved that tumor microenvironment might disturb the balance between Th17 and Treg. It is possible to assume an association between activation of CSCs which contribute to metastasis in late stages, and the imbalanced Th17/Treg cells observed in advanced gastric cancer patients. This review intends to clarify the importance of gastric tumor microenvironment specifically CSCs in relation to Th17/Tregs balance firstly and to highlight the relevance of imbalanced Th17/Treg subsets in determining the stages and behavior of the tumor secondly. Finally, the present study suggests a clinical approach looking at the plasticity of T cells with a focus on Th17 as a promising dedicated arm in cancer immunotherapy.

Keywords: gastric cancer, gastric cancer stem cells, Treg, Th17 plasticity, cancer immunotherapy

\section{INTRODUCTION}

Gastric cancer with a high prevalence is the fourth common cancer and second death leading cancer worldwide. About $90 \%$ of stomach tumors are adenocarcinomas, which are subdivided into two main histological types: undifferentiated or diffuse type, and well-differentiated or intestinal type, that respectively accounts for 28 and $23 \%$ of following lung and liver cancers. In addition to 
hereditary cases which account for $1-3 \%$ of all gastric cancers, environmental factors consist of low consumption of fruits and vegetables and high intake of salts, nitrates, and pickled foods, as well as smoking, gastro-esophageal reflux disease, and obesity have been clearly related to increased risk of gastric cancer.

Epstein-Barr virus and Helicobacter pylori ( $H$. pylori) infection cause to $80 \%$ of gastric stromal carcinoma and $70 \%$ of all gastric cancer cases worldwide (1), respectively. These indicated the important role of the immune system in gastric cancer initiation and development. Indeed, oxidative and nitrosative stress and consequent cellular and DNA damage followed by cycles of repair have been considered as important chain events in H. pylori-induced gastric carcinogenesis. Many of these events occur in chronically inflamed gastric mucosa. It is reported that the number of macrophages and dendritic cells (DCs) are increased in the infected gastric mucosa and caused to produce IL- 6 , IL- $1 \beta$, IL- 12 , tumor necrosis factor- $\alpha$ $(\mathrm{TNF}-\alpha)$, and stromal cell-derived factor $(\mathrm{SDF} 1 \alpha)$ that induce inflammation and initiation of Th1 responses. Th1 secrets IFN$\gamma$ and promotes chronic gastric inflammation. These consecutive events result in an epithelial to mesenchymal transition (EMT) and neoplastic transformation (1). Despite induction of immune response in infected individuals, $H$. pylori evades from adaptive immune response using virulent factors and subverts gastric epithelial cells which in turn mediates inhibition of $\mathrm{T}$ cell proliferation and induces Treg cells from naïve $\mathrm{T}$ cells. To this gastric epithelial cells express a high level of B7.H1 (PD-L1) (a $\mathrm{T}$ cell co-inhibitory molecule) that its interaction with PD1 leads to a reduction of $\mathrm{T}$ cells activity simultaneously with induction of Treg cells. In addition to Treg cells, other CD4 ${ }^{+}$ $\mathrm{T}$ cells including Th17 cells contribute to $\mathrm{T}$ cell responses in infection induced-immunity. It has been reported that IL-17 secreted by Th17, stimulates gastric epithelial cells to release IL8 , which leads to neutrophils recruitment and enhanced chronic inflammation (2). Chronic inflammation can provide a gradual progression from chronic gastritis to gastric atrophy, intestinal metaplasia, dysplasia that is in favor of gastric cancer promotion (3).In fact, $H$. pylori infection induces Th1 and Th17 responses to support chronic inflammation and the unsuccessful clearing of the infection. Moreover, resistance infection stimulates Treg cells to reduce immune response against $H$. pylori. All of these

\footnotetext{
Abbreviations: Th, T helper; Treg, Regulatory $\mathrm{T}$ cell; MHC, Major histocompatibility complex; TGF- $\beta$, Transforming growth factor beta; IL, Interleukin; IFN- $\gamma$, Interferon gamma; CD, Cluster of differentiation; $H$. pylori, Helicobacter pylori; EMT, Epithelial to mesenchymal transition; CCL, Motif chemokine; CXCL, Chemokine (C-X-C motif) ligand; DCs, Dendritic cells; TNF- $\alpha$, Tumor necrosis factor- $\alpha$; SDF- $1 \alpha$, Stromal cell-derived factor- $1 \alpha$; MDSCs, Myeloid-derived suppressor cells; Arg-I, Arginase I; iNOS, Inducible nitric oxide synthase; PDL-1, Programmed death-ligand 1; BMDCs, Marrowderived cells; TAMs, Tumor associated macrophages; CAFs, Cancer-associated fibroblasts; APCs, Antigen presenting cells; TILs, Tumor infiltrating lymphocytes; GMFs, Gastric myofibroblasts; MCP-1, Monocyte chemoattractant protein-1; RANTES, Regulated on activation, normal T cell expressed and secreted; PGE2, Prostaglandin E2; PGE1, Prostaglandin E1; HIF-1 $\alpha$, Hypoxia-inducible factors$1 \alpha$; VEGF, Vascular endothelial growth factor; MIP-2, Macrophage inflammatory protein-2; IDO, Indoleamine 2,3-dioxygenase; PMP, Platelet microparticles; CpGODNs, CpG oligodeoxynucleotides; pDCs, Plasmacytoid dendritic cells; TLR-9, Toll-like receptor 9 .
}

changes favor cancer progression (4). In addition, a correlation between the increased number of Th17 (5) and Treg (6) cells and course of disease was reported in the previous studies. The main concept of the present review is clarifying the role of tumor microenvironment in Th17 and Tregs induction as well as Th17/Treg balance in gastric cancer. Then we pay more attention to the role of cancer stem cells in changing the balance of Th17/Treg and its clinical perspective.

\section{THE ROLE OF THE MICROENVIRONMENT IN GASTRIC CANCER DEVELOPMENT}

Tumor microenvironment consists of diverse cell types such as tumor cells, gastric epithelial cells, tumor fibroblasts, cancer stem cells, and components of the innate and adaptive immune system. Each cell not only affects on tumor progression but also modulates immune system locally. Indeed persistent chronic inflammation provokes to damage of gastric epithelial mucosa followed by recruitment of bone marrow-derived cells (BMDCs). BMDCs fusion with local gastric epithelial cells leading to tissue remodeling, transformation, and potentially progression of malignancy (7). Moreover, fibroblasts gradually recruit from bone marrow to stomach in response to produced TGF- $\beta$ and SDF- $1 \alpha$ following the inflammation caused by H. pylori, to inhibit inflammation and repair the injury, however chronic inflammation derived-dysplasia differentiates them to cancer-associated fibroblasts (CAFs) with the potential to gastric cancer development (8). It has been also observed that CAFs constitute a major stromal compartment actively communicate with cancer cells through growth factors or inflammatory cytokines such as HGF, IL-6, TGF- $\beta$, VEGF, FGF, and CXCL12 that can promote tumorigenesis and progression (9). Crosstalk between tumor cells and other stromal cells including MSCs (10), endothelial cells (11), vascular cells, extracellular matrix, tumor-infiltrating lymphocytes (TILs) (12), and tumor-associated macrophages (TAMs) (13) consequently give rise to morphogenesis, angiogenesis, invasion and metastasis of tumor (14), and also modulate the immune system (Table 1). Mechanistically, they act through the cell to cell contact and largely by their secretome including various angiogenic factors, comprising vascular endothelial growth factor (VEGF), interleukin-8, and platelet-derived endothelial cell growth factor (PDGF) in gastric cancer that help tumor progression through escaping the active antitumor immunity (9).

Tumor infiltrated immune cells in gastric cancers are included different types of cells such as mast cells, TAMs, and TILs consist of T cells, B cells, and NK cells. The subset of T cells is represented by $\mathrm{CD}^{+}$cytotoxic $\mathrm{T}$ cells, $\mathrm{CD} 4^{+} \mathrm{T}$ helper cells, $\mathrm{CD} 45 \mathrm{RO}^{+}$ memory $\mathrm{T}$ cells, $\mathrm{NK}$ cells, and $\mathrm{FOXP}^{+}{ }^{+}$regulatory $\mathrm{T}$ cells. These cells can infiltrate stroma and tumor cells and are considered a manifestation of the host immune response against tumor cells (27).

Clinical studies have indicated that the increased number of Treg cells within TILs may be one of the reasons for insufficient antitumor immunity in cancers (28). The increasing number of Tregs also acts as a tumor promoter in early stages and even in 
TABLE 1 | Cellular components of gastric cancer microenvironment.

\begin{tabular}{|c|c|c|c|c|}
\hline & Cells & Function & Mediators & Reference \\
\hline \multirow[t]{6}{*}{ Tumor components } & Gastric cancer cells & Induce Treg cells differentiation & TGF- $\beta$ & $(15,16)$ \\
\hline & Gastric epithelial cells & $\begin{array}{l}\text { Recruitment of neutrophils and enhanced } \\
\text { inflammation }\end{array}$ & IL-8 & $(17)$ \\
\hline & $\begin{array}{l}\mathrm{CD}^{+} 4^{+} \text {gastric cancer } \\
\text { mucosa }\end{array}$ & $\begin{array}{l}\text { Mediate FoxP3+ Treg cells infiltration in early stages } \\
\text { of gastric cancer }\end{array}$ & CCL-22 / CCL-17 & (6) \\
\hline & $\begin{array}{l}\text { Tumor-derived stromal cells, } \\
\text { fibroblasts, and APCs }\end{array}$ & Recruitment and expansion of Th17 and Treg cells & IL-1 $\beta /$ IL-6 /IL-23 and TFG- $\beta$ & $(5,6,18)$ \\
\hline & Gastric epithelial cells & Inhibition of $\mathrm{T}$ cell activation & PDL-1 & (19) \\
\hline & & $\begin{array}{l}\text { Attenuation of } \mathrm{MHC}-\| \text { expression and subsequent } \\
\text { antigen presentation }\end{array}$ & TGF- $\beta$ & \\
\hline \multirow[t]{7}{*}{ Host immune system } & Neutrophils & Suppress T cells & PD-L1 & (20) \\
\hline & & Recruitment of BM-derived cells & IL-6, IL-1 $\beta$, TNF- $\alpha$, CXCL-12 & $(21)$ \\
\hline & MDSCs & Deplete arginine and suppress T cells proliferation & Arg-I, iNOS & $(22)$ \\
\hline & TAMs & $\begin{array}{l}\text { Promote the proliferation, invasion, and metastasis } \\
\text { of gastric cancer cells }\end{array}$ & CCL-5 & (23) \\
\hline & Th17 cells & $\begin{array}{l}\text { Angiogenesis } \\
\text { Tumor progression }\end{array}$ & $\mathrm{IL}-17$ & $(24-26)$ \\
\hline & Th1 cells & Cause chronic gastric inflammation & IFN- $\gamma$ & $(17)$ \\
\hline & FoxP3 ${ }^{+}$Treg cells & Limit Th17 cancer-associated inflammation & & (24) \\
\hline
\end{tabular}

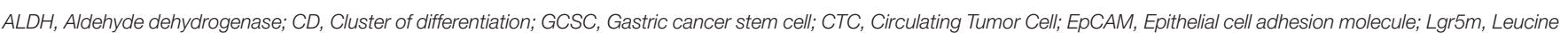
Rich Repeat Containing G Protein-Coupled Receptor 5; ABC, ATP-binding cassette.

later stages of disease which in turn, can develop progression and metastasis of cancer (29). Moreover, the increased number of Th17 in TILs detected in gastric cancer patients may also involve in gastric cancer development (5).

\section{GASTRIC CANCER AND IMMUNE MODULATION}

Gastric tumors like other tumors consist of cellular and non-cellular components while their activation promotes initialization, evasion, migration, and progression of cancer. Commonly, tumor cells evade the immune system through downregulation and impairment of the immune responses in malignancies including gastric cancer (Figure 1). One of the critical mechanisms is to interfere and attenuate antigen processing and presentation pathways, leading to the impediment of exposure of neo-antigens (30). Induction of apoptosis through Fas/FasL pathway is the other major mechanism by which tumor cells expressing FasL interact with TILs expressing Fas contributing to Fas-mediated apoptosis (31). Furthermore, immune-suppressor neutrophils expressing PD-L1 activated by tumor-derived granulocyte-macrophage colonystimulating factor (GM-CSF), have been reported to increase in gastric cancer microenvironment. The activated neutrophils subsequently suppress $\mathrm{T}$ cells through engagement of PD-L1: PD-1 inhibitory pathway leads to impairment of antitumor immunity and gastric cancer progression (20). Moreover, TAMs as one of the most frequent infiltrated population in gastric tumor stroma, inhibit antitumor $\mathrm{T}$ cell immunity and are related to poor prognosis (31). Macromolecules secreted by fibroblasts (e.g., collagen, fibronectin, and proteoglycan) as extracellular matrix not only shape the tumor and stabilize the physical structure of tumor tissue but also regulate the behavior of infiltrated immune cells inside the tumor microenvironment (32).

Another major component of infiltrated immune cells in the tumor microenvironment are Treg cells. Treg induced anergy contributes to the reversal of recognition and eradication of cancer cells via antitumor $\mathrm{T}$ cell immunity. Therefore, Treg cells play a critical role in evading antitumor immunity (30). Interestingly, a unique subpopulation of Treg cells has been identified among infiltrated immune cells in gastric cancer.

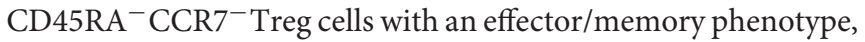
express low level of HLA-DR molecules and accumulated in tumor tissues of patients with gastric cancer. TNF- $\alpha$ produced by tumor cells induces $\mathrm{CD}^{4} \mathrm{RA}^{-} \mathrm{CCR}^{-}$Treg subset and inhibits their HLA-DR expression by phosphorylation and activation of STAT3. This immune suppressive population substantially prevents antitumor $\mathrm{CD}^{+} \mathrm{T}$ cells in vitro, while supports the tumor growth and progression via IL-10 production as well as cell to cell contact and also is associated with advanced stages of the disease and reduced survival (33).

It has been shown that gastric myofibroblasts (GMFs) that are highly-expressed MHC-II cells can induce Th17 cells differentiation from $\mathrm{CD}^{+}{ }^{+} \mathrm{T}$ cells under Th17-polarizing condition. The enriched Th17 population in inflammatory milieu might lead to the persistence of inflammation and is associated with carcinogenesis (34).

\section{Th17 AND Treg RECRUITMENT/EXPANSION BY GASTRIC CANCER COMPONENTS}

$\mathrm{CD} 4{ }^{+} \mathrm{CD} 25^{\text {hi+ }}$ Foxp $^{+}$regulatory $\mathrm{T}$ cells are known with their inhibitory activity, largely by production of TGF- $\beta$ and play a 


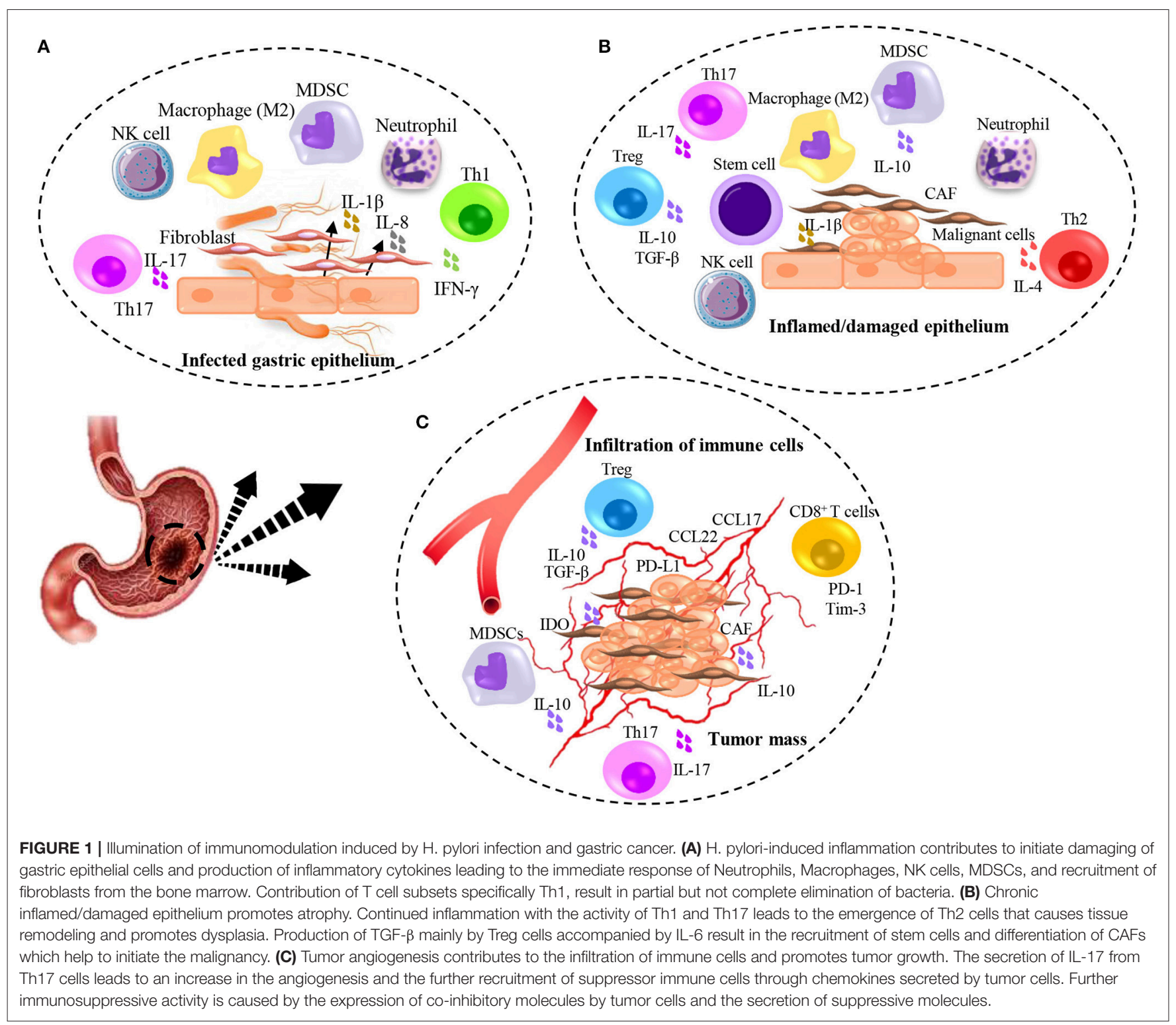

critical role in preventing autoimmunity and tumor progression (35), while IL-17 producing $\mathrm{ROR} \gamma^{+}$Th17 cells have welldescribed roles in autoimmune disease, although their role in tumor immunity remained unknown (36). As mentioned previously, gastric cancer is a clinopathology state of chronic sterile inflammation that provides an immunosuppressive condition resulting infiltration of high frequencies of both Th17 and Treg infiltration (37). Mechanistically, expression of lymphoid homing receptors including CCR4, CCR6, and also CD62L on Treg cells during cancer development leads to the gradually increased number of tumor-associated Treg cells (38) through secretion of CCL17 and CCL22 (ligands for CCR4) by tumor cells as chemotactic factors in early stages of gastric cancer (39). Indeed, tumor inflammatory milieu intelligently recruits Treg cells to suppress antitumor immunity (18). Most of the stromal cells beside gastric cancer cells have the potential of producing TGF- $\beta$ followed by activation of hypoxia-inducible factors- $1 \alpha$ (HIF- $1 \alpha)$ in the tumor microenvironment. This in turn promotes Treg infiltration (15). However, TGF- $\beta$ alone is not enough to infiltrate Treg (40) and presence of prostaglandin E2 (PGE2) and also H-Ferritin may favor for FOXP3 ${ }^{+}$cells infiltration and differentiation (16).

Although it has been frequently reported that Treg cells are significantly prevalent in gastric cancer, recent evidence has emphasized on the importance of the disturbed balance of Th17 and Treg cells in gastric cancer patients, while the ratio of Th17/Treg is obviously higher in patients with advanced gastric cancer compared to healthy controls. Furthermore, patients with lymph node metastasis have indicated a significantly increased ratio of Th17/Treg cells (24). Tumor-derived fibroblasts produce MCP-1 (CCL2) and RANTES (CCL5) could attract Th17 cells intensively. In the murine immune system, TGF- $\beta$, and, IL-6 
strongly stimulate Th17 and $\mathrm{IL}-17^{+} \mathrm{CD} 8^{+}$cells synchronously, while exogenous IL-2 significantly reduces both Th17 and IL$17^{+} \mathrm{CD} 8^{+}$cells in vitro and conversely increases the number of Treg cells. Moreover, the blockade of IL-2 leads to a decrement in number of Tregs, while enhancing $\mathrm{IL}-17^{+} \mathrm{CD} 4^{+}$and IL$17^{+} \mathrm{CD}^{+}$populations. It can be concluded that IL-2 may have opposite effects on Th17 and Treg differentiation in the murine system. This is indicative of the key role of IL-2 besides TGF- $\beta$ and IL- 6 in the regulation of Th17/Tregs balance (41). Moreover, although Th17 cells differentiation is driven by TGF- $\beta$ in mice, its role in human remained controversial (42). MDSCs, a population in tumor microenvironment also promote either Treg or Th17 cells expansion by their secretion (43). Most of the cells in tumor microenvironment recruit and expand Treg and Th17 cells through production of cytokines and chemokines (44).

\section{THE FUNCTION OF IL-17 PRODUCING CELLS IN GASTRIC CANCER: A CONTROVERSIAL STORY}

$\mathrm{CD}^{+} \mathrm{T}$ cells (Th17) and $\mathrm{CD}^{+}$IL-17 producing cells $\mathrm{T}$ cells (Tc17) have reported in patients with gastric cancer (45). It has been suggested that both $\mathrm{IL}-17^{+} \mathrm{CD} 4^{+}$and IL$17^{+} \mathrm{CD}^{+}$in tumor microenvironment can take a pathogenic role contributing to tumor progression (41). It has been also depicted that the expression of IL-17 in gastric cancer tissues and an increased number of Th17 might be related to tumor promotion due to IL-17-mediated inflammation (24). Moreover, there is evidence for the positive effect of IL-17 on the production of pro-angiogenic factors including VEGF, prostaglandin E1 (PGE1), PGE2 and macrophage inflammatory protein-2 (MIP2) by fibroblasts and tumor. In addition, vascular endothelial cell migration and cord formation stimulated by IL-17 leading to increased angiogenesis and promote tumor growth. It has been also dedicated that IL-17 can provoke production of IL8 in both epithelial cells and macrophages which in turn, may enhance the recruitment of inflammatory cells into the tumor sites. Neutrophils with or without macrophages are activated through IL-8 stimulation, and also have been related to tumor progression [77] by several mechanisms including angiogenesis and invasion (46). These data suggest that IL-17 production by Th17 $\mathrm{CD}^{+}$cells in tumor microenvironment leads to tumor progression by angiogenesis and neutrophil infiltrating in patients with gastric cancer (25). A novel subpopulation of exTh17-FoxP3 ${ }^{+}$cells has been shown to have a substantial role in tumor initiation and progression. This study has reported a dual role for this population. While ROR $\gamma$ t expression promotes an inflammatory response, the expression of FoxP3 commits the suppressor actions (47). These data propose a potential role for inflammatory Th17 cells in cancer pathogenesis.

In contrast, some other studies have suggested that increased level of IL-17 in tumor site leads to the improved antitumor immunity of TCD4 ${ }^{+} \mathrm{IL}-17^{+}$cells through inducing Ag-specific cytotoxic T cells (48), while tumor infiltrated Th17 cells per se are not able to kill or inhibit tumor cells proliferation in vitro and conversely, promote tumor progression due to the existence of TGF- $\beta$ and IL-6 in local tumor site (18). In addition, it has been reported that tumor-infiltrating Th17 cells express several effector cytokines in cancer patients, similar to that observed in patients with infectious diseases. This suggests that tumorassociated Th17 cells might also play an antitumor role in the context of the tumor. According to this possibility, Th17 cells are positively associated with effector immune cells, including cytotoxic $\mathrm{CD} 8^{+} \mathrm{T}$ cells, NK cells, and IFN $\gamma$-producing Th1 cells in the tumor microenvironment in vitro and human. Moreover, it has been documented that tumor growth and lung metastasis enhanced in many IL-17-deficient tumor models, and forced expression of IL-17 in tumor cells was shown to suppress tumor progression (49).

It has been investigated that IFN- $\gamma$-producing Th1-like cells, which seemed to be converted from $\mathrm{CD}^{+}$IL- 17 producing cells, exhibited strong cytotoxicity for the eradication of tumor cells. This conversion of Tc17 cells into Th1-like cells may be due to epigenetic modifications as seen in Th17 cells, appearing to be critical for the acquisition of the antitumor feature for Tc17 cells in tumor immunity (50). Therefore, depending on the milieu, Th17 cells can accept both pro/antitumor roles in the tumor microenvironment.

\section{Th17/Treg PLASTICITY IN GASTRIC CANCER}

Different types of T cells including Th1, Th2, Th17, and Treg cells exhibit significant developmental plasticity through epigenetic mechanisms (51) that are required to preserve homeostasis particularly in the gastrointestinal tract (52). The induction of selective gene expression that results in the development of distinct phenotypes, comes from changes in cytokine milieu that can be sensed by the signal transducer of transcription factors which in turn regulate the expression of master regulators of each lineage with the consideration of chromatin accessibility (53).

It has been suggested that FOXP3 ${ }^{+}$Treg cells might become unstable under certain inflammatory conditions and might adopt a phenotype that is more characteristic of effector $\mathrm{CD} 4^{+} \mathrm{T}$ cells (54). In addition, it was argued that loss of FoxP3 expression resulted in the capacity to become IL-17-secreting cells. Furthermore, in response to IL-12 in vitro, Treg cells can produce IFN- $\gamma(55)$.

Th17 cells have also shown the plasticity based on the milieu in which they are located and emerge the transient phenotypes with partially inflammatory and suppressive phenotype. IL$17^{+}$Foxp $^{+}{ }^{+}$cells can be derived from CCR6 ${ }^{+}$but not CCR6 ${ }^{-}$ $\mathrm{T}$ cells and play role in Th17/Treg differentiation process. They represent partially Th17 (inflammatory) and Treg (inhibitory) cells. Moreover, $\mathrm{IL}-17^{+}$Foxp $3^{+} \mathrm{T}$ cells, as proinflammatory Treg cells produce IL-17 and moderate levels of IL-2, IFN- $\gamma$, and TNF- $\alpha$ resulting in the aggravated inflammatory response (56). Identification of FoxP $3^{\text {hi }}$ and FoxP3 $3^{\text {lo }}-\mathrm{IL}-17$ producing Tregs is evidence for de novo FoxP3 expression in IL-17 producing T cells in human (57). Preclinical studies have implicated phenotypic 
markers in $\mathrm{IL}-17^{+}$Foxp $3^{+} \mathrm{T}$ cells overlapping between Treg cells and Th17 cells. This population simultaneously expresses CD25 and CCR4 that identified in Treg cells and CD161 and CD49d as Th17 cell markers (37) as well as Th17/Treg plasticity markers (58). Th17 cells also might be a source of tumorinduced $\mathrm{FoxP}^{+}$cells besides nTreg and iTreg cells which have developed from naïve $\mathrm{CD} 4^{+}$precursors (58). in addition, FoxP3 $^{+}{ }^{\mathrm{ROR}} \gamma \mathrm{t}^{+}$IL-17-producing $\mathrm{T}$ cells as an unstable lineage have detected in colon cancer (59) proposed that they can be originated from $\mathrm{FoxP}^{+}$Treg cells. This subset has preserved their immune suppressive function, while they have lost their anti-inflammatory function, Therefore regulation of the balance between Th17 and Treg subsets from a common precursor depend on the milieu and it seems that Treg cells enrichment may have a key role in Th17 development (60). Further analysis suggests that impairment of Th17-to-FoxP3 ${ }^{+} \mathrm{T}$ cells along with induction of FoxP3 ${ }^{+-}$to-Th17 (58)-to-Th1-like (61) IFN- $\gamma$ producing cells transdifferentiation can be a reliable approach for Treg cells depletion within the tumor microenvironment, due to the inability of committed Th1 to convert to Treg in Th1-Th17Treg axis (55). Studies on autoimmune disorders have shown that ex-FoxP $3^{+} \mathrm{IL}-17^{+}$cells are accumulated selectively at the inflammation sites. This is another proof of plasticity feature of FoxP3 ${ }^{+} \mathrm{T}$ cell subset, whereas the committed Treg cells are stable (62). Metabolic regulator of immune responses such as nutrient, energy, oxygen, and stress level along with transduction signals like mTOR, HIF- $1 \alpha$, and AMP-activated protein kinase (AMPK) regulate the Th17/Treg balance. Therefore, besides inter-conversion developmental factors, additional factors induce the Th17/Treg balance through transcription factors. In this context, the same signal might lead to both Th17 and Treg induction depending on the microenvironment components. For instance, PGE2 increase Th17 through the production of IL-23 and IL- $1 \beta$ by DCs and macrophages, while it can also induce expansion of IL-10 producing Treg type-1 cells (Tr1) as a result of tumor cells secretion as well as expression of COX2/PGE2 by Treg cells (63). Activation of JAK/STAT, TGF- $\beta$, STAT3 and mTOR also skew the Th17/Treg balance toward Th17 cells differentiation (64).

Recent studies have demonstrated that tumor-derived Th17 cells produce low levels of TGF- $\beta$ and IL-10 after stimulation with anti-CD3 in vitro and express CTLA4, FoxP3, and CD25 as Treg cell markers, while they do not suppress tumor progression. This in turn, confirms the developmental plasticity of Th17 cells and exhibits a yin and yang performance, meaning that Th17 infiltrating cells have either a regulatory or an antitumor role in gastric cancer microenvironment. Enhanced production of PGE2, IL-1 $\beta$, IL-6, TGF- $\beta$ as well as arginase, indoleamine 2,3dioxygenase (IDO) and IL-10 from MDSCs implicitly mediate reciprocal differentiation of Th17 and Treg cells in a defined circumstance of tumor microenvironment (65). IDO and iNOS produced by MDSCs both are critical molecules for regulation of Th17/Treg balance. Descriptively, it has been investigated that Th17 differentiation induces through IL-6R mediated pathway. In addition, iNOS/NO induces TGF- $\beta$ mediated FoxP3 ${ }^{+}$ Tregs differentiation and downregulates IL-17-mediated Th17 responses (66). Moreover, Helios, a transcription factor involved in FoxP3 ${ }^{+}$Treg cells development stability, is also associated with development of highly suppressive Treg cells (67) and is highly expressed in the tumor microenvironment (68) which in turn, might have a role in the regulation of the balance between Treg and Th17.

\section{GASTRIC CANCER STEM CELLS}

Recent findings suggest that CSCs, as immortal tumor-initiating cells with self-renewal property and pluripotent capacity, have been characterized in multiple malignancies including leukemia and different solid tumors. CSCs due to their exceptional features are responsible for tumor initiation, development, metastasis, and recurrence. Based on the CSC model, all other cells within the tumor bulk are derived from primary differentiated CSCs, without considering the existence of mutations and genetic variations during tumor development. This event named "clonal evolution model." To date, CSCs have been identified in various solid tumors including gastric cancer (69). GCSCs are defined and isolated by cellular markers expression (70) that are listed in Table 2. In addition to cellular markers, a variety of methods are used to identification and isolation of CSCs including side population, sphere formation, in vivo tumorigenicity, self-renewal capacity and signaling pathways, although these methods have advantages and disadvantages, and should be used according to the tumor types and tumor location (83). These cells exhibit potential to form tumor spheres under non-adherent cell culture conditions and form gastric tumor xenografts in immune-deficient mice (84), as well as escape from immune-mediated destruction (85). The chronic infection and $H$. pylori contribute to TGF- $\beta 1$ production that induces gastric cancer stem cells emergence that is in favor of early stages of gastric tumorigenesis and elicits an EMT (86).

CSCs similar to other tumor cells evade the immune system by changing their immunogenicity and also are capable to impair the immune response through the expression or secretion of factors impeding antitumor immune responses. Interestingly, CSCs are also able to partially mimic antigen presenting cells (APCs) with regard to MHC I and PD-L1 expressions. Elevated expression of PDL-1 on CSCs surface, inhibit T cell activation and induce anergy. CSCs secret TGF- $\beta$ in more concentration than their non-CSCs. TGF- $\beta$ secretion is associated with decreased expression of MHC II and subsequently attenuate antigen presentation, whereas it stimulates regulatory $\mathrm{T}$ cells expansion (87).

Several studies have identified a connection between innate immune cells (i.e., macrophages and MDSCs and DCs) and adaptive immune cells such as regulatory $\mathrm{T}$ cells with CSC. The immune cells could accelerate CSC-specific expansion and maintenance both directly and indirectly via their secretions. The interaction between Treg cells and CSCs largely remained obscure, but a recent study concerning the role of Treg cells in colorectal cancer has been proved that $\mathrm{FoxP} 3^{+} \mathrm{IL}-17^{+}$cells promote the expansion of CSCs by secreting of hypoxia-induced IL-17 (30). 
TABLE 2 | Gastric cancer stem cell markers.

\begin{tabular}{|c|c|c|c|c|c|}
\hline $\begin{array}{l}\text { Markers } \\
\text { ALDH high/low ,CD133, } \\
\text { CD44 }\end{array}$ & \multicolumn{3}{|c|}{ Sources } & $\begin{array}{l}\text { Main Points } \\
\text {-ALDH high GCSCs possess a high level of } \\
\text { self-renewal ability but resting stage. } \\
\text {-The ALDH } \\
\text { ability, but a rapid proliferation stage. }\end{array}$ & $\begin{array}{l}\text { Reference } \\
(71)\end{array}$ \\
\hline $\begin{array}{l}\text { CD24, CD44, Vimentin, } \\
\text { ALDH, Cytokeratin } \\
18^{\text {low }}\end{array}$ & Sphere & $\begin{array}{l}\text { MKN-45, } \\
\text { SGC7901 }\end{array}$ & & $\begin{array}{l}\text { MKN45 cells exhibited a higher sphere-forming } \\
\text { efficiency than SGC7901 cells with higher } \\
\text { expression of CD44 and CD24. }\end{array}$ & (72) \\
\hline EpCAM, CD44 & Sphere & Tumor tissue & & $\begin{array}{l}\text {-Both CD44 and EpCAM markers are needed } \\
\text { for isolation of cancer stem cells directly } \\
\text { from patients. } \\
\text {-In addition to in vivo experiments, gastric } \\
\text { cancer stem cells generate various } \\
\text { differentiated cells in cancer sphere culture. }\end{array}$ & (76) \\
\hline CD90 & Primary tumor cells & $\begin{array}{l}\text { Tumor tissue } \\
\text { Xenotransplar }\end{array}$ & & $\begin{array}{l}\text { A higher proportion of } \mathrm{CD}^{+} 0^{+} \text {cells correlates } \\
\text { with higher in vivo tumorigenicity of gastric } \\
\text { primary tumor models. }\end{array}$ & (77) \\
\hline $\begin{array}{l}\text { EPCAM, CD133, } \\
\text { CD166, CD44, } \\
\text { ALDHhigh }\end{array}$ & $\begin{array}{l}\text { Primary tumor cells } \\
\text { Cell line } \\
\text { Cell line }\end{array}$ & $\begin{array}{l}\text { Xenograft } \\
\text { MKN-45, } \\
\text { MKN-74 }\end{array}$ & $\begin{array}{l}\text { Sphere } \\
\text { Sphere }\end{array}$ & $\begin{array}{l}\text {-CD44 and ALDH are the most specific } \\
\text { biomarkers to detect and isolate tumorigenic } \\
\text { and chemoresistant gastric CSCs in noncardia } \\
\text { gastric carcinomas. } \\
\text {-Tumorigenic and chemoresistant gastric CSCs } \\
\text { co-express EPCAM, CD133, CD166, CD44, } \\
\text { and ALDH. } \\
\text {-ALDH is the most specific biomarker for CSC } \\
\text { enrichment before CD44 in both diffuse- and } \\
\text { intestinal-type noncardia gastric carcinomas. }\end{array}$ & (78) \\
\hline CD71 & Cell line & $\mathrm{MKN}-1$ & & $\begin{array}{l}\text { CD71- cells have important roles in cancer } \\
\text { development. This subtype also exhibits high } \\
\text { drug resistance to conventional chemotherapy. }\end{array}$ & (80) \\
\hline Lgr5 & $\begin{array}{l}\text { Human gastric cancer } \\
\text { and animal model }\end{array}$ & Tumor tissue & & $\begin{array}{l}\text { Gastric cancer develops when } \\
\text { cancer-associated genes are activated in } \\
\text { Lgr5-positive stem cells and change them to } \\
\text { CSCs. }\end{array}$ & (81) \\
\hline $\begin{array}{l}\text { ABCB1, ABCG2, } \\
\text { CD133 }\end{array}$ & $\begin{array}{l}\text { Human gastric cancer } \\
\text { Different differentiation } \\
\text { status cell lines } \\
\text { Xenograft } \\
\text { transplantation of } 3 \\
\text { cell lines }\end{array}$ & $\begin{array}{l}\text { Tumor tissue } \\
\text { HGC-27, } \\
\text { BGC-823, } \\
\text { SGC-7901 } \\
\text { Injected } \\
\text { HGC-27, } \\
\text { BGC-823, } \\
\text { SGC-7901 } \\
\text { cell lines }\end{array}$ & & $\begin{array}{l}\text {-The expression of the CSC markers ABCB1, } \\
\text { ABCG2, and CD133 differ in gastric cancers } \\
\text { with various degrees of differentiation. } \\
\text {-Poorly differentiated gastric cancers } \\
\text { expressing relatively more CSC markers. }\end{array}$ & (82) \\
\hline
\end{tabular}




\section{Th17/Treg PLASTICITY CAN BE POSSIBLY MORE AFFECTED BY GASTRIC CANCER STEM CELLS}

Although the polarization of Treg vs. Th17 cells via interaction with MSCs is indicated (88), the exact role of CSCs particularly GCSCs on Th17/Treg plasticity remained to be determined.

Soluble factors and cell to cell contacts are two main factors from GCSCs can affect Th17 differentiation.

\section{Soluble Mediators in Th17/Treg Polarization by GCSCs}

As we stated previously, accumulating data have indicated that a cocktail of IL-6, IL-1 $\beta$, and IL-23 could be used as dedicated cytokines for induction of Th17, whereas IL- 2 and TGF- $\beta$ have been frequently considered as stimulating factors in human Treg cells differentiation. Further analysis has suggested a dual role for CSCs to induce Treg and Th17 subsets in several cancers through alteration in cytokines balance in tumor milieu (Figure 2).

Despite intensive researches on CSCs in various cancers, there is no evidence regarding the GCSCs effect on Th17/Treg balance. Most of the evidence came from malignant tumors with a higher incidence of GCSCs. High plasma levels of platelet microparticles (PMP), VEGF, IL-6, and CCL5 in patients with stage IV vs. those in patients with stage I or stage II/III that can be related to metastatic gastric cancer (89) and gastric cancer stem cells activation.

IL-6 that is important in Th17 differentiation, as well as cancer-associated inflammation, was detected in oral squamous cell carcinoma (90) and in vitro culture of KM22, a breast cancer cell line (91). Alternatively, it was determined that IL6 is produced by CSCs in multiple myeloma, breast cancer (22), and Squamous cell carcinoma with a relatively significant concentration (92) rather than other cancer cells. Similarly, IL-23 produced by ovarian CSCs (93) has been frequently reported that plays an important role in maturation and maintenance of Th17 cells phenotype. Of note, TGF- $\beta$ a critical cytokine for induction of Treg cells and inhibition of Th17 cells differentiation has been detected in adenocarcinoma, squamous cell carcinoma and lung cancer cell lines (94), although it was produced in more concentration by CSCs in squamous cell carcinoma (92). In addition, CCL5 a chemokine that strongly attracts Th17 and Treg cells has been detected in breast cancer at primary and metastatic tumor sites, ovarian, gastric, and prostate cancers (95). Accordingly, some other cytokines produced by tumor mass might induce Th17 and Treg differentiation by crosstalk with the similar internal adaptors. IL8 produced by many types of cancers (94) has been demonstrated that significantly secreted by squamous cell carcinoma CSCs (92), and it can trigger differentiation of Th17 cells through simultaneous activation of STAT3 with IL-6. Similarly, VEGF produced by MKN-45 as a gastric cancer cell line (96), might

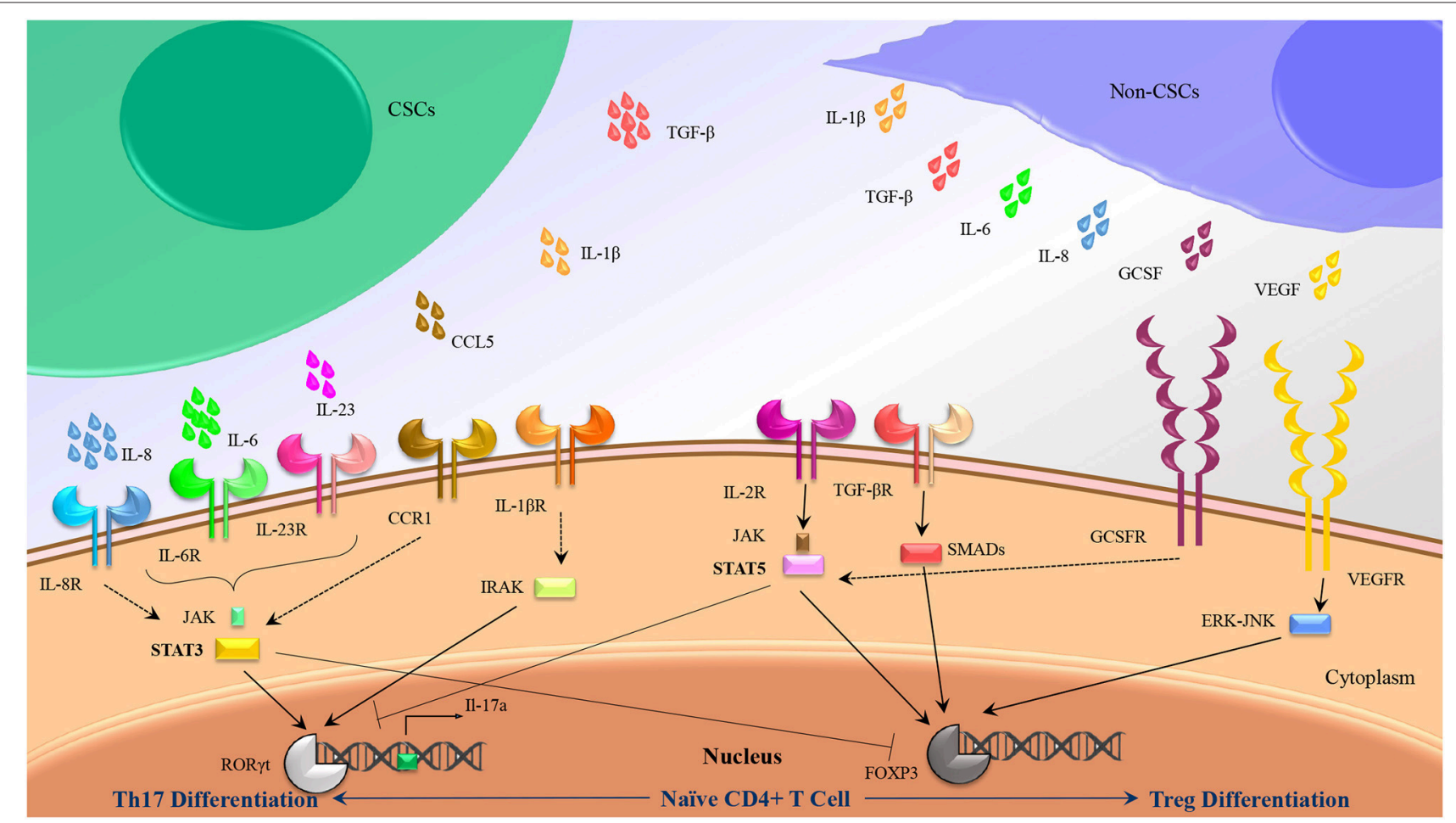

FIGURE 2 | Th17/Treg polarization might be influenced by CSC secretions rather than non-CSC secretions. Besides intrinsic mediators associated to Th17 (IL-1 $\beta$, IL-6, and II-23) and Treg (TGF- $\beta$, IL-2) differentiation, some other cytokines produced by CSCs and non-CSCs might induce Th17 and Treg differentiation by crosstalk with the similar internal adaptors. 
induce Treg differentiation through ERK-JNK signaling pathway activation $(97,98)$.

\section{Direct Communication Between GCSCs and T Cells}

In addition to soluble factors secreted by CSCs that have effect on Th17/Treg balance, existence of stemness genes in Th17 cells (it will be discussed in part 5) can potentiate this hypothesis that they can transfer between CSCs and $\mathrm{CD}^{+} \mathrm{T}$ cells through cell to cell communication. This in turn, can induce Th17 cells differentiation. Diverse mechanisms of intercellular communication have been already well documented including chemical synapses, gap junctions, and plasmodesmata. High sensitive nanotubular structures can be established probably between immune cells, tumor cells, and also between infiltrating $\mathrm{T}$ cells and distant tumor cells, facilitate simplify selective transfer and communication (99). Thereupon, stemness genes might transfer from CSCs to $\mathrm{T}$ cells through tunneling nanotubes and differentiate CD4+ T cells to long-lived Th17 stem-like cells. STAT3, a pleiotropic transcription factor activated downstream of cytokines, is overexpressed in gastric cancer stem cells and metastatic tumor samples (100). Activated STAT3 can be either pro-oncogenic or tumor-suppressive according to the tumor etiology and mutational landscape (101), and it considers as a critical transcription factor for Th17 differentiation, while represses the development of Tregs (102). Therefore, we can conclude that STAT3 might be able to pass through membrane structures between gastric cancer stem cells and Treg/CD4 ${ }^{+}$ uncommitted $\mathrm{T}$ cells to change the shift them to Th17 cells.

The tumor's immune cell polarization changes are basically beneficial to the tumor, leading to escape from the immune system and tumor progression. However, the antitumor or protumor activity of Th17 cells induced by GCSCs should be investigated.

\section{FUTURE PROSPECTIVE}

While CSCs are a small population among tumor cells, their importance in immune modulation should not be neglected. These cells produced a high concentration of soluble factors that differ from other tumor cells, therefore determine the fate of Th17 and Treg cells by changing in differentiation, recruitment. Thus, the imbalanced Th17/Treg in peripheral blood and tumor tissues could be considered as new hallmarks of CSCs activity and metastasis.

Recently, cancer immunotherapy aims to elicit the activity of CTLs within a tumor, strengthening the helper $\mathrm{CD} 4^{+} \mathrm{T}$ cells function can improve the efficiency of antitumor activity of CTLs, clonal expansion, and providing effector and memory CTL (103). Although most researches have focused on immune activation using $\mathrm{T} \mathrm{CD} 8+$ and even $\mathrm{CD} 4+$, the exact role of Th17 and its potential in immune cell therapy remained unknown. In the present study, we reviewed the characteristic of Th17 cells, as they are not fully differentiated subset with self-renewal ability, sustained survival, capable of plasticity, and representing stem cell-like memory cells features. They have been reported as a precursor of Th1 cell-like cells producing IFN$\gamma$ and $\mathrm{CD}^{+}$cytotoxic cells which play an important role in antitumor immunity (104). Hence, they could be considered to be promising for using in cancer immunotherapy strategies. Two strategies including:

\section{Conversion of FoxP3 ${ }^{+} \mathrm{CD}^{+}{ }^{+}$Treg Cells to the Hybrid Th17/Th1 to Elicit a Potent and Prolonged Antitumor Immune Response}

In contrast to Th17, Th1 as a key player in antitumor immunity possessing functional mediators including IFN- $\gamma^{\text {hi }}, \mathrm{CD} 107 \mathrm{a}^{\text {hi }}$, Tbet $^{\text {hi }}$, and Granzyme- $B^{\text {hi }}$ as markers of activities are not able to persist in tumor microenvironment to show a long-term effect probably due to the lack of stem cell features. Recent data has been shown that KLF4, a key transcription factor in pluripotency of stem cells, binding to the promoter of Il17a plays a critical role in Th17 differentiation but not in other subsets of helper $\mathrm{T}$ cells (105). Moreover, the long-lived Th17 cells with the capacity of plasticity, exhibit an increase in expression of genes associated with self-renewal including HIF-1a, Notch, Bcl2, OCT4, and Nanog (106). In addition, Th17 cells do not express PD-1, FoxP3, KLRG-1, CD57, and IL-10, therefore they are not a candidate for being functionally exhausted $\mathrm{PD}-1^{+} \mathrm{T}$ cells, suppressive Foxp $^{+}$, IL- $10^{+} \mathrm{T}$ cells or senescent $\mathrm{CD} 28^{-} \mathrm{CD} 57^{+} \mathrm{KLRG}^{-1^{+} \mathrm{T}}$ cells (106).

We propose an approach to convert $\mathrm{CD}^{+} \mathrm{FoxP}^{+}$cells isolated from patients to transient ex-FoxP3 ${ }^{+}$Th17 cells. Th17 cells have been observed to be able to switch to ex-Th17IFN$\gamma^{+}$from IFN- $\gamma^{+} \mathrm{IL}-17^{+}$cells in autoimmune diseases and inflammatory infections (50). Therefore, the next step would be the differentiation of Th17/Th1 as desired cells with an antitumor activity by providing proper cytokine cocktail. We suggest that the combination of the potent Th1 effectiveness with the stemness features of Th17 to produce hybrid Th17/Th1 in human and mouse can be more efficient to control tumor progression compared to Th1 or Th17 alone as previously reported in melanoma. The hybrid Th17/Th1 has exhibited a potent effector function and an increased persistence with less susceptibility to induced cell death through activity (107). Although it might be more challenging to identify and keep the hybrid phenotype.

\section{Production of Tc17/CTL Population From FoxP3 $^{+} \mathrm{CD}^{+}{ }^{+}$Treg Cells With Higher Potential of Antitumor Immunity}

It has been documented that Tc17 cells show no strong cytotoxicity, whereas plastically changed IL-17/IFN- $\gamma$ cells through epigenetic modification (108) have a strong antitumor effect. Cultivation of Tc17 cells with further IL-12 convert them to IL-17/IFN- $\gamma$ double producing cells with acquired cytotoxic function in vitro and in vivo (50). Therefore, we propose a strategy in order to convert $\mathrm{CD} 8{ }^{+} \mathrm{FoxP}^{+}$cells into exFoxp $3^{+}$Tc17 cells and then into the Tc17/CTL population which plays a crucial role as final effector cells with cytotoxicity in the tumor microenvironment. 


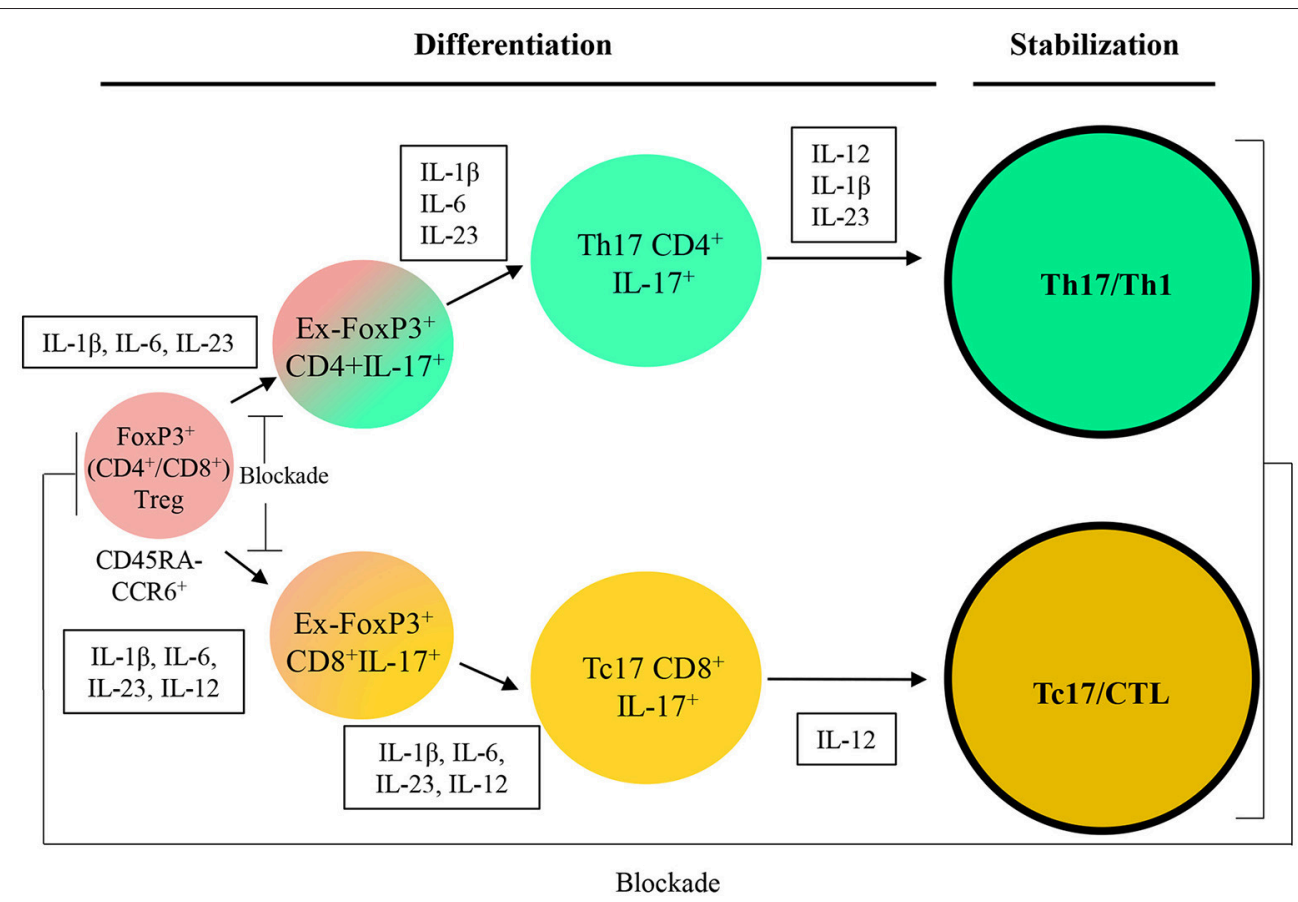

FIGURE 3 | A therapeutic approach based on Treg/Th17/Th1 axis. IL, Interleukin; CCL, C-C motif chemokine; CXCL, Chemokine (C-X-C motif) ligand; APC, Antigen-presenting cells; TGF- $\beta$, Transforming growth factor beta; PDL-1, Programmed death-ligand 1; MHC, Major histocompatibility complex; MDSC, Myeloid-derived suppressor cell; Arg-I, Arginase I; iNOS, Inducible nitric oxide synthase; TAM, Tumor-associated macrophage; IFN- $\gamma$, Interferon-gamma.

Further attempt for the two strategies is would be focusing on stabilization of induced (reactivated) antitumor immune cells by keeping the one-way conversion of inefficient to efficient cells as well as blocking internal pathways to unfavored cell fates (Figure 3). We believe that recent strategies are able to bring new insight to apply $\mathrm{T}$ cells plasticity in cancer immunotherapy and suggest that this feature can be used as a promising approach in the treatment of cancers and also autoimmune diseases.

\section{CONCLUSION}

Accumulating evidence suggests that CSCs including GCSCs can have a greater effect on Th17/Treg balance than other tumor cells. Therefore, the observation of imbalanced Th17/Treg in liquid biopsy of cancer patient's blood could be considered as a diagnostic marker for activation of CSCs. In addition, a change in the axis of Th17/Treg indicates that CSCs alter the balance between them through the plasticity of $\mathrm{T}$ cells with the focus on Th17 plasticity. Therefore, this feature can be an opportunity and uses in immunotherapy of cancers to convert the patient's inefficient cells into active and antitumor cells to remove the tumor.

\section{REFERENCES}

1. Kim SS, Ruiz VE, Carroll JD, Moss SF. Helicobacter pylori in the pathogenesis of gastric cancer and gastric lymphoma. Cancer Lett. (2011) 305:228-38. doi: 10.1016/j.canlet.2010.07.014

\section{AUTHOR CONTRIBUTIONS}

AR contributed to develop the theory, data collection, and was the major contributor in writing the manuscript. HA contributed to data collection and data analysis. EA was involved in data collection, drafting and writing the manuscript. GS revised the manuscript and supervised this work. ME developed the theory, revised the manuscript, and supervised this work. All authors read and approved the final manuscript.

\section{FUNDING}

This review is derived from a project has been conducted by grants from Hamadan University of Medical Sciences and Royan Institute for Stem Cell Biology and Technology, Cancer Research Center of Cancer Institute of Iran (Sohrabi cancer charity, Grant No: 37381-202-01-97) also funded publishing the manuscript.

\section{ACKNOWLEDGMENTS}

The authors thank Arsalan Jalili for providing English proofreading.

2. Lina TT. Immune evasion strategies used by Helicobacter pylori. World J Gastroenterol. (2014) 20:12753. doi: 10.3748/wjg.v20.i36. 12753

3. Fox JG, Wang TC. Inflammation, atrophy, and gastric cancer. J Clin Invest. (2007) 117:60. doi: 10.1172/JCI30111 
4. Larussa T, Leone I, Suraci E, Imeneo M, Luzza F. Helicobacter pylori and T helper cells: mechanisms of immune escape and tolerance. I Immunol Res. (2015) 2015:981328. doi: 10.1155/2015/981328

5. Zhang B, Rong G, Wei H, Zhang M, Bi J, Ma L, et al. The prevalence of Th17 cells in patients with gastric cancer. Biochem Biophys Res Commun. (2008) 374:533-7. doi: 10.1016/j.bbrc.2008.07.060

6. Maruyama T, Kono K, Mizukami Y, Kawaguchi Y, Mimura K, Watanabe M, et al. Distribution of Th17 cells and FoxP3(+) regulatory T cells in tumorinfiltrating lymphocytes, tumor-draining lymph nodes and peripheral blood lymphocytes in patients with gastric cancer. Cancer Sci. (2010) 101:1947-54. doi: 10.1111/j.1349-7006.2010.01624.x

7. Hutchinson L, Stenstrom B, Chen D, Piperdi B, Levey S, Lyle S, et al. Human Barrett's adenocarcinoma of the esophagus, associated myofibroblasts, and endothelium can arise from bone marrow-derived cells after allogeneic stem cell transplant. Stem Cells Dev. (2010) 20:11-7. doi: 10.1089/scd.2010.0139

8. Quante M, Tu SP, Tomita H, Gonda T, Wang SS, Takashi S, et al. Bone marrow-derived myofibroblasts contribute to the mesenchymal stem cell niche and promote tumor growth. Cancer Cell. (2011) 19:257-72. doi: 10.1016/j.ccr.2011.01.020

9. Kitadai Y. Cancer-stromal cell interaction and tumor angiogenesis in gastric cancer. Cancer Microenviron. (2010) 3:109-16. doi: 10.1007/s12307-009-0032-9

10. Tsai KS, Yang SH, Lei YP, Tsai CC, Chen HW, Hsu CY, et al. Mesenchymal stem cells promote formation of colorectal tumors in mice. Gastroenterology. (2011) 141:1046-56. doi: 10.1053/j.gastro.2011.05.045

11. Hamerlik P, Lathia JD, Rasmussen R, Wu Q, Bartkova J, Lee M, et al. Autocrine VEGF-VEGFR2-Neuropilin-1 signaling promotes glioma stemlike cell viability and tumor growth. J Exp Med. (2012) 209:507-20. doi: 10.1084/jem.20111424

12. Kasashima H, Yashiro M, Nakamae H, Masuda G, Kinoshita H, Morisaki T, et al. Bone marrow-derived stromal cells are associated with gastric cancer progression. Br J Cancer. (2015) 113:443. doi: 10.1038/bjc.2015.236

13. Jinushi M, Chiba S, Yoshiyama H, Masutomi K, Kinoshita I, Dosaka-Akita H, et al. Tumor-associated macrophages regulate tumorigenicity and anticancer drug responses of cancer stem/initiating cells. Proc Natl Acad Sci USA. (2011) 108:12425-30. doi: 10.1073/pnas.1106645108

14. Meyers RA. Encyclopedia of Molecular Cell Biology and Molecular Medicine. Weinheim: Wiley-VCH Verlag. (2004).

15. Yuan X-L, Chen L, Zhang T-T, Ma Y-H, Zhou Y-L, Zhao Y, et al. Gastric cancer cells induce human CD4+ Foxp3+ regulatory $\mathrm{T}$ cells through the production of TGF- $\beta 1$. World J Gastroenterol. (2011) 17:2019. doi: 10.3748/wjg.v17.i15.2019

16. Beyer M, Schultze JL. Review article regulatory $\mathrm{T}$ cells in cancer. Blood. (2006) 108:804-11. doi: 10.1182/blood-2006-02-002774

17. Bessede E, Dubus P, Megraud F, Varon C. Helicobacter pylori infection and stem cells at the origin of gastric cancer. Oncogene. (2015) 34:2547. doi: 10.1038/onc.2014.187

18. Su X, Ye J, Hsueh EC, Zhang Y, Hoft DF, Peng G. Tumor microenvironments direct the recruitment and expansion of human Th17 cells. J Immunol. (2010) 184:1630-41. doi: 10.4049/jimmunol.0902813

19. Francisco LM, Salinas VH, Brown KE, Vanguri VK, Freeman GJ, Kuchroo VK, et al. PD-L1 regulates the development, maintenance, and function of induced regulatory T cells. J Exp Med. (2009) 206:3015-29. doi: 10.1084/jem.20090847

20. Wang TT, Zhao YL, Peng LS, Chen N, Chen W, Lv YP, et al. Tumouractivated neutrophils in gastric cancer foster immune suppression and disease progression through GM-CSF-PD-L1 pathway. Gut. (2017) 66:190011. doi: 10.1136/gutjnl-2016-313075

21. Takaishi S, Okumura T, Wang TC. Gastric cancer stem cells. J Clin Oncol. (2008) 26:2876-82. doi: 10.1200/JCO.2007.15.2603

22. Wang L, Chang EW, Wong SC, Ong SM, Chong DQ, Ling KL. Increased myeloid-derived suppressor cells in gastric cancer correlate with cancer stage and plasma S100A8/A9 proinflammatory proteins. J Immunol. (2013) 190:794-804. doi: 10.4049/jimmunol.1202088

23. Ding H, Zhao L, Dai S, Li L, Wang F, Shan B. CCL5 secreted by tumor associated macrophages may be a new target in treatment of gastric cancer. Biomed Pharmacother. (2016) 77:142-9. doi: 10.1016/j.biopha.2015. 12.004
24. Li Q, Li Q, Chen J, Liu Y, Zhao X, Tan B, et al. Prevalence of Th17 and Treg cells in gastric cancer patients and its correlation with clinical parameters. Oncol Rep. (2013) 30:1215-22. doi: 10.3892/or.2013.2570

25. Iida $T$, Iwahashi $M$, Katsuda $M$, Ishida $K$, Nakamori $M$, Nakamura M, et al. Tumor-infiltrating CD4+ Th17 cells produce IL-17 in tumor microenvironment and promote tumor progression in human gastric cancer. Oncol Rep. (2011) 25:1271-7. doi: 10.3892/or.2011.1201

26. Bettelli E, Korn T, Oukka M, Kuchroo VK. Induction and effector functions of T H 17 cells. Nature. (2008) 453:1051. doi: 10.1038/nature07036

27. Sawayama $\mathrm{H}$, Ishimoto $\mathrm{T}, \mathrm{Baba} \mathrm{H}$. Microenvironment in the pathogenesis of gastric cancer metastasis. J Cancer Metastasis Treat. (2018) 4:10. doi: 10.20517/2394-4722.2017.79

28. Wang R-F. Regulatory $\mathrm{T}$ cells and innate immune regulation in tumor immunity. Sem Immunopathol. (2006) 28:17-23. doi: 10.1007/s00281-006-0022-7

29. Wrzesinski SH, Wan YY, Flavell RA. Transforming growth factor- $\beta$ and the immune response: implications for anticancer therapy. Clin Cancer Res. (2007) 13:5262-70. doi: 10.1158/1078-0432.CCR-07-1157

30. Sultan M, Coyle KM, Vidovic D, Thomas ML, Gujar S, Marcato P. Hideand-seek: The interplay between cancer stem cells and the immune system. Carcinogenesis. (2017) 38:107-18. doi: 10.1093/carcin/bgw115

31. Subhash VV, Yeo MS, Tan WL, Yong WP. Strategies and Advancements in harnessing the immune system for gastric cancer immunotherapy. $J$ Immunol Res. (2015) 2015:308574. doi: 10.1155/2015/308574

32. Lu P, Weaver VM, Werb $\mathrm{Z}$. The extracellular matrix: a dynamic niche in cancer progression. J Cell Biol. (2012) 196:395-406. doi: $10.1083 /$ jcb.201102147

33. Mao FY, Kong $\mathrm{H}$, Zhao YL, Peng LS, Chen W, Zhang JY, et al. Increased tumor-infiltrating CD45RA- CCR7- regulatory T-cell subset with immunosuppressive properties foster gastric cancer progress. Cell Death Dis. (2017) 8:e3002. doi: 10.1038/cddis.2017.388

34. Pinchuk IV, Morris KT, Nofchissey RA, Earley RB, Wu J-Y, Ma TY, et al. Stromal cells induce Th17 during Helicobacter pylori infection and in the gastric tumor microenvironment. PLoS ONE. (2013) 8:e53798. doi: 10.1371/journal.pone.0053798

35. Kondelkova K, Vokurková D, Krejsek J, Borská L, Fiala Z, Ctirad A. Regulatory T cells (TREG) and their roles in immune system with respect to immunopathological disorders. Acta Medica. (2010) 53:73-7.

36. Tesmer LA, Lundy SK, Sarkar S, Fox DA. Th17 cells in human disease. Immunol Rev. (2008) 223:87-113. doi: 10.1111/j.1600-065X.2008.00628.x

37. Kryczek I, Wu K, Zhao E, Wei S, Vatan L, Szeliga W, et al. IL-17+ regulatory $\mathrm{T}$ cells in the microenvironments of chronic inflammation and cancer. $J$ Immunol. (2011) 186:4388-95. doi: 10.4049/jimmunol.1003251

38. Curiel TJ, Coukos G, Zou L, Alvarez X, Cheng P, Mottram P, et al. Specific recruitment of regulatory $\mathrm{T}$ cells in ovarian carcinoma fosters immune privilege and predicts reduced survival. Nat Med. (2004) 10:942-9. doi: $10.1038 / \mathrm{nm} 1093$

39. Mizukami Y, Kono K, Kawaguchi Y, Akaike H, Kamimura K, Sugai H, et al. CCL17 and CCL22 chemokines within tumor microenvironment are related to accumulation of Foxp3 + regulatory T cells in gastric cancer. Int J Cancer. (2008) 122:2286-93. doi: 10.1002/ijc.23392

40. Zhao X, Ye F, Chen L, Lu W, Xie X. Human epithelial ovarian carcinoma cell-derived cytokines cooperatively induce activated CD4+CD25CD45RA+ naïve $\mathrm{T}$ cells to express forkhead box protein 3 and exhibit suppressive ability in vitro. Cancer Sci. (2009) 100:2143-51. doi: 10.1111/j.1349-7006.2009.01286.x

41. Kryczek I, Wei S, Zou L, Altuwaijri S, Szeliga W, Kolls J, et al. Cutting edge: Th17 and regulatory $\mathrm{T}$ cell dynamics and the regulation by IL-2 in the tumor microenvironment. J Immunol. (2007) 178:6730-3. doi: 10.4049/jimmunol.178.11.6730

42. Kretschmer K, Apostolou I, Hawiger D, Khazaie K, Nussenzweig MC, Boehmer HV. Inducing and expanding regulatory $\mathrm{T}$ cell populations by foreign antigen. Nat Immunol. (2005) 6:1219-27. doi: 10.1038/ni1265

43. Obermajer N, Popp FC, Soeder Y, Haarer J, Geissler EK, Schlitt HJ, et al. Conversion of Th17 into IL-17Aneg regulatory T cells: a novel mechanism in prolonged allograft survival promoted by mesenchymal stem cell-supported minimized immunosuppressive therapy. J Immunol. (2014) 193:4988-99. doi: 10.4049/jimmunol.1401776 
44. Volpe E, Servant N, Zollinger R, Bogiatzi SI, Hupé P, Barillot E, et al. A critical function for transforming growth factor-beta, interleukin 23 and proinflammatory cytokines in driving and modulating human $\mathrm{T}(\mathrm{H})-17$ responses. Nat Immunol. (2008) 9:650-7. doi: 10.1038/ni.1613

45. Zhuang Y, Peng LS, Zhao YL, Shi Y, Mao XH, Chen W, et al. CD8+ $\mathrm{T}$ cells that produce interleukin-17 regulate myeloid-derived suppressor cells and are associated with survival time of patients with gastric cancer. Gastroenterology. (2012) 143:951-62.e8. doi: 10.1053/j.gastro.2012.06.010

46. Benelli R, Albini A, Noonan D. Neutrophils and angiogenesis: potential initiators of the angiogenic cascade. In: Cassatella MA, editor. The Neutrophil vol 83. Basel: Karger Publishers. (2003). p. 167-81.

47. Zhou L, Lopes JE, Chong MMW, Ivanov II, Min R, Gabriel D, et al. TGF$\beta$-induced Foxp3 inhibits Th17 cell differentiation by antagonizing ROR $\gamma \mathrm{t}$ function. Nature. (2008) 453:236-40. doi: 10.1038/nature06878

48. Hirahara N, Nio Y, Sasaki S, Minari Y, Takamura M, Iguchi C, et al. Inoculation of human interleukin-17 gene-transfected Meth-A fibrosarcoma cells induces T cell-dependent tumor-specific immunity in mice. Oncology. (2001) 61:79-89. doi: 10.1159/000055357

49. Zou W, Restifo NP. T H 17 cells in tumour immunity and immunotherapy. Nat Rev Immunol. (2010) 10:248. doi: 10.1038/nri2742

50. Tajima M, Wakita D, Satoh T, Kitamura H, Nishimura T. IL-17/IFN- $\gamma$ double producing CD8+ T (Tc17/IFN- $\gamma$ ) cells: a novel cytotoxic T-cell subset converted from Tc17 cells by IL-12. Int Immunol. (2011) 23:751-9. doi: $10.1093 /$ intimm/dxr086

51. Lee YK, Turner H, Maynard CL, Oliver JR, Chen D, Elson CO, et al. Late developmental plasticity in the T helper 17 lineage. Immunity. (2009) 30:92-107. doi: 10.1016/j.immuni.2008.11.005

52. Garrido-Mesa N, Algieri F, Nogales AR, Gálvez J. Functional plasticity of Th17 cells: implications in gastrointestinal tract function. Int Rev Immunol. (2013) 32:493-510. doi: 10.3109/08830185.2013. 834899

53. Hirahara K, Vahedi G, Ghoreschi K, Yang XP, Nakayamada S, Kanno Y, et al. Helper T-cell differentiation and plasticity: insights from epigenetics. Immunology. (2011) 134:235-45. doi: 10.1111/j.1365-2567.2011.03483.x

54. Sakaguchi S, Vignali DA, Rudensky AY, Niec RE, Waldmann H. The plasticity and stability of regulatory T cells. Nat Rev Immunol. (2013) 13:4617. doi: $10.1038 /$ nri3464

55. Muranski P, Restifo NP. Essentials of Th17 cell commitment and plasticity. Blood. (2013) 121:2402-14. doi: 10.1182/blood-2012-09-378653

56. Du R, Zhao H, Yan F, Li H. IL-17+Foxp3+ T cells: an intermediate differentiation stage between Th17 cells and regulatory T cells. J Leukoc Biol. (2014) 96:39-48. doi: 10.1189/jlb.1RU0114-010RR

57. Kim J, Kwon J, Kim M, Do J, Lee D, Han H. Low-dielectric-constant polyimide aerogel composite films with low water uptake. Polymer J. (2016) 48:829-34. doi: 10.1038/pj.2016.37

58. Downs-Canner S, Berkey S, Delgoffe GM, Edwards RP, Curiel T, Odunsi K, et al. Suppressive IL-17A+ Foxp3+ and ex-Th17 IL-17AnegFoxp3+ Treg cells are a source of tumour-associated Treg cells. Nat Commun. (2017) 8:14649. doi: $10.1038 /$ ncomms 14649

59. Blatner NR, Mulcahy MF, Dennis KL, Scholtens D, Bentrem DJ, Phillips $\mathrm{JD}$, et al. Expression of ROR $\gamma \mathrm{t}$ marks a pathogenic regulatory $\mathrm{T}$ cell subset in human colon cancer. Sci Trans Med. (2012) 4:164ra59-ra59. doi: 10.1126/scitranslmed.3004566

60. Marks BR, Nowyhed HN, Choi J-Y, Poholek AC, Odegard JM, Flavell RA, et al. Thymic self-reactivity selects natural interleukin 17-producing T cells that can regulate peripheral inflammation. Nat Immunol. (2009) 10:1125-32. doi: $10.1038 /$ ni. 1783

61. Hirota K, Duarte JH, Veldhoen M, Hornsby E, Li Y, Cua DJ, et al. Fate mapping of IL-17-producing $\mathrm{T}$ cells in inflammatory responses. Nat Immunol. (2011) 12:255-63. doi: 10.1038/ni.1993

62. Komatsu N, Okamoto K, Sawa S, Nakashima T, Oh-hora M, Kodama T, et al. Pathogenic conversion of Foxp3 $+\mathrm{T}$ cells into TH17 cells in autoimmune arthritis. Nat Med. (2014) 20:62-8. doi: 10.1038/nm.3432

63. Gagliani N, Amezcua Vesely MC, Iseppon A, Brockmann L, Xu H, Palm N, et al. Th17 cells transdifferentiate into regulatory $\mathrm{T}$ cells during resolution of inflammation. Nature. (2015) 523:221-5. doi: 10.1038/nature14452

64. Naghavian R, Ghaedi K, Kiani-Esfahani A, Ganjalikhani-Hakemi M, Etemadifar M, Nasr-Esfahani MH. miR-141 and miR-200a, revelation of new possible players in modulation of Th17/Treg differentiation and pathogenesis of multiple sclerosis. PLOS ONE. (2015) 10:e0124555. doi: 10.1371/journal.pone.0124555

65. Obermajer N, Wong JL, Edwards RP, Chen K, Scott M, Khader S, et al. Induction and stability of human Th17 cells require endogenous NOS2 and cGMP-dependent NO signaling. J Exp Med. (2013) 210:1433-46. doi: 10.1084/jem.20121277

66. Jayaraman P, Alfarano MG, Svider PF, Parikh F. iNOS expression in CD4 p T cells limits treg induction by repressing TGF b 1 : combined iNOS Inhibition and Treg depletion unmask endogenous antitumor immunity. Clin Cancer Res. (2014) 2:6439-52. doi: 10.1158/1078-0432.CCR-13-3409

67. Sugita K, Hanakawa S, Honda T, Kondoh G, Miyachi Y, Kabashima K, et al. Generation of Helios reporter mice and an evaluation of the suppressive capacity of Helios (+) regulatory T cells in vitro. Exp Dermatol. (2015) 24:554-6. doi: 10.1111/exd.12711

68. Wainwright DA, Sengupta S, Han Y, Lesniak MS. Thymus-derived rather than tumor-induced regulatory $\mathrm{T}$ cells predominate in brain tumors. NeuroOncol. (2011) 13:1308-23. doi: 10.1093/neuonc/nor134

69. Chen K, Huang Y-h, Chen J-l. Understanding and targeting cancer stem cells: therapeutic implications and challenges. Acta Pharmacol Sinica. (2013) 34:732-40. doi: 10.1038/aps.2013.27

70. Fu Y, Li $\mathrm{H}$, Hao $\mathrm{X}$. The self-renewal signaling pathways utilized by gastric cancer stem cells. Tumour Biol. (2017) 39:1010428317697577. doi: 10.1177/1010428317697577

71. Shang $\mathrm{Z}, \mathrm{Xu} \mathrm{Y}$, Liang $\mathrm{W}$, Liang $\mathrm{K}, \mathrm{Hu} \mathrm{X}$, Wang L, et al. Isolation of cancer progenitor cells from cancer stem cells in gastric cancer. Mol Med Rep. (2017) 15:3637-43. doi: 10.3892/mmr.2017.6423

72. Wang X, Zou F, Deng H, Fu Z, Li Y, Wu L, et al. Characterization of sphereforming cells with stemlike properties from the gastric cancer cell lines MKN45 and SGC7901. Mol Med Rep. (2014) 10:2937-41. doi: $10.3892 / \mathrm{mmr} .2014 .2601$

73. Zhang X, Hua R, Wang X, al. e. Identification of stem-like cells and clinical significance of candidate stem cell markers in gastric cancer. Oncotarget. (2016) 7:9815-31. doi: 10.18632/oncotarget.6890

74. Zhang C, Li C, He F, Cai Y, Yang H. Identification of CD44+CD24+ gastric cancer stem cells. J Cancer Res Clin Oncol. (2011) 137:1679-86. doi: 10.1007/s00432-011-1038-5

75. Chen T, Yang K, Yu J, Meng W, Yuan D, Bi F, et al. Identification and expansion of cancer stem cells in tumor tissues and peripheral blood derived from gastric adenocarcinoma patients. Cell Res. (2012) 22:248-58. doi: $10.1038 / \mathrm{cr} .2011 .109$

76. Han ME, Jeon TY, Hwang SH, Lee YS, Kim HJ, Shim HE, et al. Cancer spheres from gastric cancer patients provide an ideal model system for cancer stem cell research. Cell Mol Life Sci. (2011) 68:3589-605. doi: 10.1007/s00018-011-0672-Z

77. Jiang J, Zhang Y, Chuai S, Wang Z, Zheng D, Xu F, et al. Trastuzumab (herceptin) targets gastric cancer stem cells characterized by CD90 phenotype. Oncogene. (2012) 31:671-82. doi: 10.1038/onc.20 11.282

78. Nguyen PH, Giraud J, Chambonnier L, Dubus P, Wittkop L, Belleannee $G$, et al. Characterization of biomarkers of tumorigenic and chemoresistant cancer stem cells in human gastric carcinoma. Clin Cancer Res. (2017) 23:1586-97. doi: 10.1158/1078-0432.CCR-152157

79. Lau WM, Teng E, Chong HS, Lopez KA, Tay AY, Salto-Tellez M, et al. CD44v8-10 is a cancer-specific marker for gastric cancer stem cells. Cancer Res. (2014) 74:2630-41. doi: 10.1158/0008-5472.CAN-13-2309

80. Ohkuma M, Haraguchi N, Ishii H, Mimori K, Tanaka F, Kim HM, et al. Absence of CD71 transferrin receptor characterizes human gastric adenosquamous carcinoma stem cells. Ann Surg Oncol. (2012) 19:1357-64. doi: 10.1245/s10434-011-1739-7

81. Leushacke M, Tan SH, Wong A, Swathi Y, Hajamohideen A, Tan LT, et al. Lgr5-expressing chief cells drive epithelial regeneration and cancer in the oxyntic stomach. Nat Cell Biol. (2017) 19:774-86. doi: 10.1038/ncb3541

82. Jiang Y, He Y, Li H, Li H-N, Zhang L, Hu W, et al. Expressions of putative cancer stem cell markers ABCB1, ABCG2, and CD133 are correlated with the degree of differentiation of gastric cancer. Gastric Cancer. (2012) 15:440-50. doi: $10.1007 /$ s10120-012-0140-y 
83. Abbaszadegan MR, Bagheri V, Razavi MS, Momtazi AA, Sahebkar A, Gholamin M. Isolation, identification, and characterization of cancer stem cells: a review. J Cell Physiol. (2017) 232:2008-18. doi: 10.1002/jcp.25759

84. Takaishi S, Okumura T, Tu S, Wang SS, Shibata W, Vigneshwaran R, et al. Identification of gastric cancer stem cells using the cell surface marker CD44. Stem Cells. (2009) 27:1006-20. doi: 10.1002/stem.30

85. Bruttel VS, Wischhusen J. Cancer stem cell immunology: key to understanding tumorigenesis and tumor immune escape? Front Immunol. (2014) 5:360. doi: 10.3389/fimmu.2014.00360

86. Choi YJ, Kim N, Chang H, Lee HS, Park SM, Park JH, et al. Helicobacter pylori-induced epithelial-mesenchymal transition, a potential role of gastric cancer initiation and an emergence of stem cells. Carcinogenesis. (2015) 36:553-63. doi: 10.1093/carcin/bgv022

87. Silver DJ, Sinyuk M, Vogelbaum MA, Ahluwalia MS, Lathia JD. The intersection of cancer, cancer stem cells, and the immune system: therapeutic opportunities. Neuro-Oncol. (2016) 18:153-9. doi: 10.1093/neuonc/nov157

88. Patel SA, Dave MA, Bliss SA, Giec-Ujda AB, Bryan M, Pliner LF, et al. Treg/Th17 polarization by distinct subsets of breast cancer cells is dictated by the interaction with mesenchymal stem cells. J Cancer Stem Cell Res. (2014) 2014:e1003. doi: 10.14343/JCSCR.2014.2e1003

89. Kim HK, Song KS, Park YS, Kang YH, Lee YJ, Lee K, et al. Elevated levels of circulating platelet microparticles, VEGF, IL-6 and RANTES in patients with gastric cancer: possible role of a metastasis predictor. Eur J Cancer. (2003) 39:184-91. doi: 10.1016/S0959-8049(02)00596-8

90. Yamamoto T, Kimura T, Ueta E, Tatemoto Y, Osaki T. Characteristic cytokine generation patterns in cancer cells and infiltrating lymphocytes in oral squamous cell carcinomas and the influence of chemoradiation combined with immunotherapy on these patterns. Oncology. (2003) 64:40715. doi: 10.1159/000070300

91. Eichbaum C, Meyer A-S, Wang N, Bischofs E, Steinborn A, Bruckner T, et al. Breast cancer cell-derived cytokines, macrophages and cell adhesion: implications for metastasis. Anticancer Res. (2011) 31:3219-27.

92. Chikamatsu K, Takahashi G, Sakakura K, Ferrone S, Masuyama K. Immunoregulatory properties of CD44+ cancer stem-like cells in squamous cell carcinoma of the head and neck. Head Neck. (2011) 33:208-15. doi: 10.1002/hed.21420

93. Wang D, T X, Zhongquan Z, Kailong L, Pin Y, Lupin J, et al. Autocrine interleukin-23 promotes self-renewal of CD133+ ovarian cancer stem-like cells. Oncotarget. ( 2016) 7:76006-20. doi: 10.18632/oncotarget.12579

94. Fukuyama T, Ichiki Y, Yamada S, Shigematsu Y, Baba T, Nagata $\mathrm{Y}$, et al. Cytokine production of lung cancer cell lines: correlation between their production and the inflammatory/immunological responses both in vivo and in vitro. Cancer Sci. (2007) 98:1048-54. doi: 10.1111/j.1349-7006.2007.00507.x

95. Aldinucci D, Colombatti A. The inflammatory chemokine CCL5 and cancer progression. Mediators Inflamm. (2014) 2014:292376. doi: $10.1155 / 2014 / 292376$

96. Koga A, Aoyagi K, Imaizumi T, Miyagi M, Shirouzu K. Comparison between the gastric cancer cell line MKN-45 and the high-potential peritoneal dissemination gastric cancer cell line MKN-45P. Kurume Med J. (2011) 58:73-9. doi: 10.2739/kurumemedj.58.73
97. Lee C-C, Chen S-C, Tsai S-C, Wang B-W, Liu Y-C, Lee H-M, et al. Hyperbaric oxygen induces VEGF expression through ERK, JNK and cJun/AP-1 activation in human umbilical vein endothelial cells. J Biomed Sci. (2006) 13:143-56. doi: 10.1007/s11373-005-9037-7

98. Zhang YE. Non-Smad pathways in TGF- $\beta$ signaling. Cell Res. (2009) 19:128. doi: 10.1038/cr.2008.328

99. Rustom A, Saffrich R, Markovic I, Walther P, Gerdes H-H. Nanotubular highways for intercellular organelle transport. Science. (2004) 303:1007-10. doi: 10.1126/science.1093133

100. Hajimoradi M, Mohammad Hassan Z, Ebrahimi M, Soleimani M, Bakhshi $\mathrm{M}$, Firouzi J, et al. STAT3 is overactivated in gastric cancer stem-like cells. Cell J. (2016) 17:617-28. doi: 10.22074/cellj.2016.3834

101. Avalle L, Camporeale A, Camperi A, Poli V. STAT3 in cancer: a double edged sword. Cytokine. (2017) 98:42-50. doi: 10.1016/j.cyto.2017.03.018

102. Chaudhry A, Rudra D, Treuting $\mathrm{P}$, et al. $\mathrm{CD}^{+}{ }^{+}$regulatory $\mathrm{T}$ cells control TH17 responses in a Stat3-dependent manner. Science. (2009) 326:986-91. doi: 10.1126/science. 1172702

103. Borst J, Ahrends T, Babala N, Melief CJM, Kastenmuller W. CD4(+) T cell help in cancer immunology and immunotherapy. Nat Rev Immunol. (2018) 18:635-47. doi: 10.1038/s41577-018-0044-0

104. Muranski P, Borman Zachary A, Kerkar Sid P, Klebanoff Christopher A, Ji Y, Sanchez-Perez L, et al. Th17 cells are long lived and retain a stem cell-like molecular signature. Immunity. (2011) 35:972-85. doi: 10.1016/j.immuni.2011.09.019

105. An J, Golech S, Klaewsongkram J, Zhang Y, Subedi K, Huston GE, et al. Kruppel-like factor 4. (KLF4) directly regulates proliferation in thymocyte development and IL-17 expression during Th17 differentiation. FASEB J. (2011) 25:3634-45. doi: 10.1096/fj.11-186924

106. Wei S, Zhao E, Kryczek I, Zou W. Th17 cells have stem cell-like features and promote long-term immunity. OncoImmunology. (2014) 1:516-9. doi: 10.4161 /onci.19440

107. Chatterjee S, Daenthanasanmak A, Chakraborty P, Wyatt MW, Dhar P, Selvam SP, et al. CD38-NAD+axis regulates immunotherapeutic anti-tumor $\mathrm{T}$ cell response. Cell Metab. (2017) 27:85-100.e8. doi: 10.1016/j.cmet.2017.10.006

108. Satoh T, Tajima M, Wakita D, Kitamura H, Nishimura T. The development of IL-17/IFN- $\gamma$-double producing CTL s from T c17 cells is driven by epigenetic suppression of S ocs3 gene promoter. Eur J Immunol. (2012) 42:2329-42. doi: $10.1002 /$ eji.201142240

Conflict of Interest Statement: The authors declare that the research was conducted in the absence of any commercial or financial relationships that could be construed as a potential conflict of interest.

Copyright (C) 2019 Rezalotfi, Ahmadian, Aazami, Solgi and Ebrahimi. This is an open-access article distributed under the terms of the Creative Commons Attribution License (CC BY). The use, distribution or reproduction in other forums is permitted, provided the original author(s) and the copyright owner(s) are credited and that the original publication in this journal is cited, in accordance with accepted academic practice. No use, distribution or reproduction is permitted which does not comply with these terms. 